\title{
ÚJ TÍPUSÚ EGYSÉGES TANÁRKÉPZÉS \\ VAGY A BOLOGNAI TANÁRI MESTERKÉPZÉS \\ KORREKCIÓS MODELLJE? \\ HOGYAN TOVÁBB A TANÁRKÉPZÉSBEN?
}

\author{
HELYZETELEMZÉSI KÍSÉRLET \\ ÉS MEGVALÓSÍTÁSI JAVASLATOK
}

\section{CSERNUS SÁNDOR ${ }^{*}$ - FORGÁCS TAMÁs ${ }^{* *}$}

* a Szegedi Tudományegyetem Bölcsészettudományi Karának dékánja

** a Szegedi Tudományegyetem Bölcsészettudományi Karának dékánhelyettese

\begin{abstract}
Alábbi írásunk egy nagyjából tíz oldalas vitaanyag nagyon tömör összefoglalása, mely tartalmaz az elmúlt hónap megbeszélései során felvetett új elemeket is. Az eredetiben számba vettük a problémákat, és kisérletet tettünk arra, hogy a tanárképzés osztatlan rendszeréhez köthetö és a bolognai-rendszerben meglévö pozitív elemeket összekapcsoljuk és - mindkét rendszer erényeit összebékitve - felvázoljunk egy olyan modellt, melynek segitségével az új típusú tanárképzés eredményessége lényegesen javitható volna. A cél nyilvánvalóan az, hogy a tanárképzés valódi elitképzés legyen. Világossá kell azonban tennünk, hogy ennek a célnak az elérése érdekében a képzés tartalmi javitását célzó szerkezeti átalakitás nem elegendö: a felsőoktatás - és ezen belül különösen a tanárképzés - fejlesztési koncepciója nem szakitható el a közoktatás rendszerétől, és tekintettel kell lennie a társadalom igényeire, értékrendjére és tanári hivvatás anyagi és társadalmi megbecsültségére. Amíg a tanári átlagfizetés Magyarországon alig éri el a hazai diplomás átlagfizetés kétharmadát, elitképzésben gondolkodni ugyan lehet, de ennek az elit csoportnak a társadalomban elfoglalt presztízse alatta fog maradni a várakozásoknak. Mindezek elörebocsátása mellett, az alábbiakban ezúttal alapvetöen a meglévö igényeket és potenciált tartalmilag is optimalizálni képes, szerkezeti átalakításokra vonatkozó javaslatainkat foglaljuk össze.
\end{abstract}

1. Az elmúlt hónapokban egyre markánsabb módon jelent meg a magyar oktatásügyben az az igény, hogy a bolognai-rendszert föladva vissza kell állítani az osztatlan tanárképzés rendszerét. Meggyőződésünk azonban, hogy a felelősségteljes döntéshez igen alapos elemzésre és egyeztetésre van szükség. Meggyőződésünk, hogy még egy kapkodó átalakítást ez a megtépázott rendszer már nagyon nehezen viselne el. 
Ugyanakkor tudvalévő, hogy a ma sem mindig megfelelően teljesítő közoktatásban még kizárólag olyan pedagógusok tanítanak, akik a korábbi, osztatlan rendszerben végeztek. Ez óvatosságra kell, hogy intse a döntéshozókat, hiszen úgy tünik, hogy az osztatlan rendszer visszaállítása önmagában biztosan nem hozhatja meg a remélt változást. Új helyzet van, amire új válaszokat kell adni. Ezért azt a kérdést tettük föl magunknak, hogy lehetséges-e a két rendszer legpozitívabb elemeinek az összeegyeztetése, s hogy ennek milyen szakmai feltételei vannak? (Az alábbiakban több olyan kérdést is érintünk, melyek a felsőoktatás egészének a problémáira vonatkoznak, ugyanakkor fontosnak tartjuk kiemelésüket, mert figyelembe vételük a tanárképzés helyzetét is nagymértékben befolyásolja.)

2. A múvelődéspolitikai, az oktatási és szakmai kommunikációban mind elterjedtebb felfogássá válik az a nézet, mely szerint a „,bolognai tömegesitéssel” szemben az egységes képzések képesek voltak megőrizni presztízsüket és korábbi pozícióikat. Nyilvánvaló azonban, hogy a két képzési forma közötti színvonalkülönbségben legalább ekkora szerepet játszik a szakmák presztízse is. A még mindig tekintéllyel rendelkező orvosképzésbe, például eleve jobb képességű hallgatók jelentkeznek.

Emellett a közgazdaságtudományi vagy a nemzetközi szakos osztott képzéseken kevéssé hallani a bolognai-rendszer hátrányairól, s ennek nyilvánvalóan az a fó oka, hogy a középfokú oktatásból ezekre a területekre a színvonalasabb tanulmányi eredményeket produkáló, nívósabb tudású, többnyire „elitebb” családi hátterü hallgatók érkeznek. Mindezekből fakad, hogy a következő párhuzamok: az osztatlan képzés $=$ elitképzés $=$ színvonal, míg az osztott képzés $=$ tömegképzés $=$ színvonalhiány, ebben a mechanikus formában nem állíthatók fel.

A hiba nem ott van, hogy milyen Magyarországon a diplomások, illetve a felsőoktatásban lévők lakossághoz viszonyított aránya (ezt a nemzetközi összehasonlításban elfogadhatónak tarthatjuk), hanem ott, hogy a tömegképzést az oktatáspolitika „beleengedte” a korábbi elitképzési struktúrákba, majd azokat széttörve megpróbálta újraszerkeszteni a rendszert oly módon, hogy nem garantálta a minőségi szelekció és tartalmi fejlődés lehetőségét. Söt, az arra való törekvést a finanszírozási rendszer valójában inkább büntette, mint ösztönözte. Ez az egész felsőoktatási rendszer erkölcsi tartását is kikezdte. (Évek óta rendre bort prédikálunk, és vizet iszunk...)

3. Kérdés tehát számunkra ezúttal az, hogy megoldható-e hogy az egységes és osztatlan tanárképzés újrafogalmazott igénye (és a mögötte megfogalmazódó jobbítási szándék) s a bolognai képzési rendszer értékei egymásra találjanak, $\mathrm{s}$ ennek következtében a lehető legrövidebb időn belül a rendszerben valamiféle minőséget javító kompromisszum jöjjön létre? Úgy véljük, hogy van erre lehetöség. De kezdjük a problémákkal. 
A bolognai tanári MA-val szemben rendre megfogalmazott leggyakoribb kifogások közé tartozik, hogy széttöredezett, valójában nem kétszakos, hanem csak „másfél-szakos” tanárokat képez, hogy a kétciklusú képzés szakmailag nem elég koherens, illetve, hogy probléma van a gyakorlatorientáltsággal, és túlságosan nagy a „pedagógiai-pszichológiai” modul súlya a képzésen belül. (Ez utóbbi probléma szinte minden eddigi szakmai tanácskozás során felvetődött, tehát ezzel kezdenünk kell valamit.)

Ugyancsak a problémák között szerepel (s a színvonalnak és a presztízsnek is erőteljesen árt) a 2-3 féléves kiegészítő jellegü tanárszakok ügye, különösen olyan körülmények között, amikor „elözönlötték” a tanári mesterképzést a szakmai előzmények nélküli - gyakran nomenklatúrájukban is igen sajátos elnevezésü - mesterszakok (a multikulturális nevelés tanára, bábjátéktanár és társaik), amelyeknek valójában sokkal inkább a szakirányú továbbképzés területén lenne létjogosultságuk.

4. A mesterszintü tanárképzés szakmai színvonalának garantálása érdekében lényegesnek tartjuk, hogy ez a képzés mindenekelőtt az oktatási téren is kiemelkedő szerepet játszó kutatóegyetemekhez, illetve kiválósági központokhoz kapcsolódjék. (Mint ismeretes, pl. orvosképzés olyan elitképzés, melyet hazánkban négy nagy oktatási és egyben tudományos központ lát el. A tanári mesterképzési programoknak nem automatikusan kellene követni ezt a logikát, de mindenképpen figyelembe kellene vennie. Valószínüleg aligha kerülhető el, hogy itt is meghatároztassanak és nevesíttessenek - még ha az előbbiekhez képest sokkal rugalmasabban is - országos tanári mesterképzési keretszámok és központok.)

5. Ugyanakkor nagyon fontosnak tartjuk, hogy azok a további képző intézmények, amelyekben ma tanárképzés, illetve pedagógusképzés folyik, és amelyek az adott régióban nem egyszerüen csak oktatási központok, hanem a helyi társadalom életében komplex funkciókat töltenek be, megtalálják a helyüket a rendszerben. Ehhez azonban meg kellene változtatni azt a finanszírozással is félreorientált belső szerkezeti logikát, mely ezeknek az intézményeknek az esetében is a minél magasabb szintü (BA+MA+ doktori) képzések megvalósításán keresztül kínálják a kitörés lehetőségét. Ezeket a kérdéseket külön, egy erre a problémakörre koncentráló anyagban kellene felmérni, és az érintettek bevonásával zajló szakmapolitikai egyeztetés során megtárgyalni.

6. Az alábbiakban megpróbálunk egy olyan modellt felvázolni, amely a jelenlegi kétszintü képzést nem gyökerestül forgatja fel, viszont miközben tekintettel van az osztatlanság elónyeire, sokkal kiegyensúlyozottabb arányokat biztosít a két szak között, egyúttal - arra az esetre, ha valaki rájön, hogy mégsem akar tanár lenni - viszonylag kevés „vargabetüvel” módot ad a kétszintű képzésbe való visszatérésre is, illetve más kimenetet is lehetővé tesz. 
Ennek a megoldásnak több elönye is van. Az egyik, hogy ha az osztatlan tanárképzés valami forradalmian új szakstruktúra vagy akár a régi tanárképzési tantervekre alapozva jönne létre, akkor öt, de legalább négy képzéstípus maradna a rendszerben, ami nyilvánvalóan oktatásszervezési nehézségeket okoz, és a diszciplináris területekkel is konfliktusokhoz vezethet.

A másik ok az, hogy az osztatlan tanárképzés ellenzői közül sokan megkérdőjelezik, szerencsés dolog-e az, hogy a tanár szakos hallgatónak már 18 éves korábban meg kell hoznia azt az egzisztenciális döntést, hogy ö később tanár akar lenni, s ha így dönt, akkor később már csak igen komoly pályakorrekcióval lesz képes más szakmák felé váltani. Tekintsünk el most attól, hogy mennyire jogos ez a felvetés, hiszen egy orvos vagy egy jogász is 18 évesen hozza meg ezt a pályaválasztási döntést, $\mathrm{s}$ ha harmadévesen jön rá, hogy ö bizony újságíró vagy színész szeretne lenni, akkor éppolyan komoly korrekcióra kényszerül, mint egy „pályatévesztett” tanár. Próbáljunk viszont a lehetséges képzési szerkezettel elébe menni ennek a problémának.

Ez a két fentebb említett tényező azt a praktikus megoldást kívánná meg, hogy az osztatlan tanárképzés nagyjából a mai képzéseinkre épüljön, azokból táplálkozzon, de más belső arányokkal és kreditszámokkal. Sőt, azt sem tartjuk kizártnak, hogy a szakmai szempontok figyelembevételével akár új kurzusok is kerüljenek a rendszerbe.

A megoldás egyik lehetséges útja tehát az lehetne, ha a jelenlegi képzést úgy módosítanánk, hogy az új osztatlan tanárképzésre jelentkezők diszciplináris területen nagyrészt a mai BA-rendszer óráit látogatnák, de nem 120-50 szakmai kredit arányban, hanem az első három évben pl. 90 kreditet teljesítenének a ma „főszak”nak tekinthetö képzésükön, s az 50 helyett 80 -at a másikon. Így már sokkal kiegyensúlyozottabb lenne a szakmai tudásuk szerkezete. Emellett a 10 pedagógiaipszichológiai kreditet kötelezően előre kellene hozni az első tanévre (1-2. szemeszter). Ennek az lehetne az értelme, hogy a fentebb említett pályaválasztási bizonytalanságot oldaná.

Akik ezeknek az óráknak a nyomán ugyanis úgy éreznék, mégsem akarnak tanárok lenni, így még minden további nélkül vissza tudnának szállni a bölcsész, illetve természettudományos „BA-vonatra”, s a továbbiakban 120-50-10 kreditaránnyal, azaz a ma megszokott módon folytathatnák tanulmányaikat. A mai rendszer tehát itt annyiban módosulna csupán, hogy a tanár szakosok a normál BA-szakok 120 kreditjéből 30-cal kevesebbet végeznének el, ugyanakkor a másik szakjukon a mai 50 kredit mellé a szak 120 kredites változatából - irányított módon, előre meghatározva, mely tárgyakról van szó - további 30 kreditet. Épp ez tenné lehetővé az esetleges későbbi pályakorrekciót, hiszen ha időben jön rá a hallgató, hogy nem tanár akar lenni, akkor a „főszak” 90 kreditje mellé megszerzi a maradék 30-at, a mellékszakon pedig elegendő neki az 50 kredit. 
Az osztatlan tanárképzés azonban - értelemszerüen - nem szakadna meg a 6. félév után, hanem egyenes vonalúan folytatódna tovább. A továbbiakban - szakmai mérlegelés alapján - feltehetően a mai tanári MA-szakok 40 kredites blokkjának tantárgyait volna érdemes tanulniuk, hiszen ezek többnyire olyan ismereteket tartalmaznak, amelyek az iskolai oktatás szempontjából relevánsak.

Ebben az esetben - nagyjából megtartva a mai 6+4 féléves szerkezetet, de azt diplomakiadással és új felvételivel meg nem bontva - a következő struktúra alakulhatna ki az általunk javasolt „új típusú” osztatlan tanárképzés számára.

1. táblázat: Lehetséges struktúra

\begin{tabular}{|l|c|c|c|c|}
\hline & 1. szak & 2. szak & $\begin{array}{c}\text { pedagógiai-pszichológiai } \\
\text { modul }\end{array}$ & Összesen \\
\hline 1-6. félév & $90 \mathrm{kredit}$ & $80 \mathrm{kredit}$ & $10 \mathrm{kredit}$ & $\mathbf{1 8 0}$ kredit \\
\hline 7-10. félév & $30 \mathrm{kredit}$ & $40 \mathrm{kredit}$ & $40 \mathrm{kredit}$ & $\mathbf{1 2 0}$ kredit \\
\hline Összesen: & $\mathbf{1 2 0}$ kredit & $\mathbf{1 2 0}$ kredit & $\mathbf{5 0}$ kredit & $\mathbf{3 0 0}$ kredit \\
\hline
\end{tabular}

Mindezekhez társulhat továbbra is a 11. félévben az egybefüggő szakmai gyakorlatok rendszere, ha a szakma fenntartja annak szükségességét, $\mathrm{s}$ a források is rendelkezésre állnak.

7. Az itt felvázolt modell előnye lehet, hogy két szakmailag azonos súlyú tanárszak végzését tenné lehetővé, ami munkaerőpiaci szempontból kétségtelenül „fajsúlyosabb” tudást képvisel, mint a mai „másfél szakos” megoldás, emellett módot ad - a képzés kezdeti szakaszaiban minden különösebb probléma nélkül - a pályakorrekcióra nem tanári szakok irányába is. Tudatában vagyunk annak, hogy mindez jó eséllyel feltételezi a tanári mesterszakok újra akkreditálásának szükségességét, de ha ez által javítani lehet a végzett tanárok tárgyi tudásának és képzettségének szintjét, akkor ezt a munkát - különösen, ha bírjuk hozzá a megfelelő oktatáspolitikai támogatást - el kell tudni végeznünk.

A fenti javaslatok természetesen a tanárképzés átalakításának csak egyik lehetséges irányát rajzolják meg. Ha ez a modell elfogadhatónak látszik, akkor nyilván sokkal részletesebb kifejtésére van szükség és sokoldalú egyeztetésre a szakmacsoportok képviselőivel. Mint jeleztük, meg vagyunk arról győződve, hogy a képzési szerkezet átalakítása korántsem elegendő önmagában a tanárképzés minőségi megújításához, ehhez több, egymással összefüggő intézkedésre van szükség.

Közülük a legfontosabb a tanári szakma presztízsének általános növelését célzó intézkedések meghozatala, a megfelelő és a tehetséges hallgatókat a tanári pályára vonzó bérezés kialakítása (s az ehhez kapcsolódó követelmény- és teljesítménymérési rendszer kidolgozása), egy valódi - nemcsak a középiskolai eredményeken 
alapuló, hanem lehetőség szerint a pályaalkalmasságot is mérő - felvételi rendszer újbóli bevezetése, az oktatási folyamat során következetesen alkalmazható minőségi szelekció biztosítása egy olyan szilárd finanszírozási rendszerben, mely a minőséget és a teljesítményt, nem pedig csak a mennyiséget honorálja.

Ezzel összefüggésben is elengedhetetlennek tartjuk, hogy mielőbb foglalkozzunk a belépő évfolyamok felkészültségében meglévő hiányosságok kiküszöbölésével, a hiányzó tudásanyag pótlásának módozataival. Ez nem csak a tanárképzés bemeneti problémája, hanem jóval általánosabb kérdés, ugyanakkor a tanárképzés esetében kiemelt fontosságot kaphat és a felvételi, illetve szakmai-tanulmányi orientáció szempontjából is releváns lehet.

8. A tanárképzés vonzóvá tétele érdekében a leginkább sürgető lépések közé tartozik egy olyan, szignifikáns előnyöket kínáló ösztöndíjrendszer bevezetése, mely a jó képességü és a tanári pályára is alkalmas hallgatókat orientálja a tanári hivatás irányába. Ez azonban feltételez egyfajta rövid, közép és hosszabb távra tervezö nemzeti „státusgazdálkodást”, hiszen az ösztöndíjak mennyiségét a jól megfizethető és jól megfizetett, tervezhető tanári álláshelyek számához célszerü igazítani.

9. Anyagunk ezúttal nem foglalkozik a diszciplináris képzés tartalmi kérdéseivel, annak minőségét adottnak veszi. (Ezzel persze nem azt akarjuk mondani, hogy ezen a téren minden teljesen rendben van, csak azt, hogy az egy másik fejezet.) Egyrészt, mert úgy érezzük, hogy a tanárképzésnek és a diszciplináris képzésnek egymástól nem szabad elszakadnia, másrészt mert a diszciplináris képzések színvonalának javítása nyilvánvalóan közös érdek. Úgy véljük, hogy a tanári mesterképzés megvalósítására hivatott intézményeknek rendelkezniük kell, és többnyire rendelkeznek is olyan diszciplináris kínálattal, mely lehetővé teszi a tanárszakok szakmai kurzusainak a koncepciózus és kellően rangos feltöltését.

Nincs szó tehát arról, hogy a karokon folyó diszciplináris képzéseket alárendelnénk a tanárképzés szempontjainak. Javaslataink éppen arra irányulnak, hogy a diszciplináris képzések lehetőségei és kínálata a lehető legjobban hasznosítódjék a tanárképzési programokban. Elképzelhetőnek - sőt kívánatosnak - tartjuk azonban, hogy a tanárképzésben egy olyan irányított szakmai képzés valósuljon meg, mely támaszkodik (sőt, az eddigiekhez képest más módon támaszkodik) a diszciplináris terület alap- és mesterszintủ kínálatára, és - szükség szerint - generál olyan további kurzusokat is, melyek közvetlenül szolgálják a tanárképzés érdekeit. Ezek azonban csak a tanárképzési akkreditációs folyamatban jelennének meg, tehát a diszciplináris szakokat nem érintenék, következésképp semmiképpen nem tételeznék föl a diszciplináris alap- és mesterszakok újraakkreditálásának szükségességét.

10. Eddigi megbeszéléseink során világossá vált, hogy valamennyi tanulmány, illetve tervezet magán hordozza a készítőinek saját szakmájukhoz kötődő elképzeléseit, 
az intézményi sajátosságokat, szerkezetet, a történetileg kialakult tapasztalataikat. Tudatában vagyunk annak, hogy ez a mi esetünkben is nagy valószínüséggel így van, de úgy véljük, hogy ez nem föltétlenül hátrány.

Ezzel együtt tervezetünk összeállításánál - áttekintve a különböző fórumok vonatkozó elképzeléseiben megfogalmazott problémákat és javaslatokat - igyekeztünk figyelemmel lenni minden általunk belátható szempontra, és egy olyan kompromisszumos javaslatot elöterjeszteni, melyben jelen vannak a rendszer belső átstrukturálásához szükséges tervezhetőség, a határozottság, az irányítottság, a rugalmasság, a minőség és a hatékonyság elemei. Úgy véljük, hogy ez a megközelítés lehetőséget nyújt arra is, hogy - bizonyos határokon belül - megjelenjenek (megmaradjanak) a rendszerben az adott intézmény sajátosságai, képzéseinek sokszínüsége és tekintettel tudjunk lenni a sajátos intézményi érdekekre is.

Ennek azonban nézetünk szerint vannak bizonyos korlátai: jelenlegi tudásunk szerint nem tartanánk szerencsésnek, ha vélt vagy valós diszciplináris vagy éppen intézményi érdekek, sajátosságok és határok mentén szétválna (mintegy „két-sebességessé" lenne) a tanárképzés; vagyis az egyik szakmaterületen (bölcsészeti) maradna a „bolognai”, a másik területen (természettudományos, esetleg müszaki) pedig beindulna osztatlan tanárképzés. Hogy az általunk fölvázolt modellt ,új típusú tanári mesterképzésnek”, vagy a „,bolognai tanári mesterképzés új modelljének” hívhatjuk az valószínüleg tartalom, arányok és egy kissé marketing kérdése is.

Mindenestre nyilvánvaló, hogy a megoldandó feladat igen összetett, s mivel oktatási rendszerünk gyengéi nemzetünk erejét és fejlődési lehetőségeit is gyengítik, a lehető legrövidebb időn belül, de felelősséggel s közép- és hosszabb távú koncepcióval hozzá kellene fognunk. Ha a legkülönbözöbb helyekröl annyian mondják, mondjuk, hogy a tanárképzés mostani helyzetén sürgősen változtatni kell, akkor úgy véljük, valóban itt az idő, hogy cselekedjünk, s a lehető legrövidebb határidőn belül igyekezzünk lépni. Javaslataink elönyének tartjuk, hogy - ha a fö irányokban egyetértés van - a szükséges átalakítási munkálatok szinte azonnal beindíthatók. 